\title{
THE INFLUENCE OF STUDENT TEAM ACHIVEMENET (STAD) TO THE STUDENTS' LEARNING OUTCOMES IN CIVICS SUBJECT AT CLASS X OF STATE SENIOR HIGH SCHOOL 7 BINJAI
}

\author{
Heryansyah Ginting \\ heryansyaghinting@gmail.com \\ Elementary Education, School of Postgraduate, State University of Medan, Indonesia
}

\begin{abstract}
This study aims to determine the effect of STAD cooperative learning model on student learning outcomes in Civics subjects in class X SMA Negeri 7 Binjai. The problem identification in this research is the lack of student's interest in the subject matter, this is because in general the Civics subject uses lecturing and rote method, lack of facilities for Civics subjects, and low student learning outcomes. The formulation of the problem in this research is whether there is influence of Cooperative STAD learning model on student learning outcomes in Civics subject. The type of research used in this study is experimental research. While the method used is quantitative method. Hypothesis in this research is there is influence of STAD type cooperative learning model to student learning result in civics (PPKn) subject. The population in this study amounted to 36 people and the sample in this study amounted to 20 people who said population samples taken by using simple random sampling technique or taking sample members of the population conducted randomly. The average value of the pretest result of students is 56.75 with a standard deviation of 282.30. And for the average value of posttest result of student equal to 77,75 with standard deviation 1296, 11. From result of calculation of hypothesis test got $r \_h=2,48$ and $r_{-} t$ lies 0,444 . So there is influence of Cooperative STAD learning model on student learning outcomes in the eyes of Civics class X SMA 7 Binjai. With $r_{-}$(count) (2.48) and $r_{-}$tabel (0.444). With $t_{-}$(count) 4.65> 1.73. From $r_{-}$(table) it shows that there is influence between two variables.
\end{abstract}

Keywords: Student Team Achievement, Students' Learning Outcomes, Civics Subject

\section{INTRODUCTION}

The role of Civic Education subjects is for students' intellectual, social, and emotional development as well as a key determinant to success in learning a particular field. The function of the Civic Education course is as a field of study to prepare students to reflect on their own experiences and the experiences of others, to express ideas and feelings and to understand the various nuances of meaning. While its usefulness is to help students recognize themselves, their culture, other people's cultures, express ideas and feelings, participate in society, make responsible decisions at the personal and social 
levels within themselves. Besides knowing the role, function, and usage of Civics subjects, as a teacher is also needed to be able to apply some teaching methods, so that the teaching paradigm can be changed into learning paradigm as the demands of government regulation ${ }^{1}$.

The weaknesses that occur during the learning process that has been done so far that causes the low learning outcomes of students are certainly not entirely caused by outside factors such as teacher busyness, household circumstances, the environment and others. The weaknesses are of course also influenced by factors from within the teacher itself such as willingness to prepare better materials, including the willingness of teachers themselves to apply teaching methods that have been obtained in college. In addition, teachers also can not form a conducive learning space and less able to develop teaching skills that can attract students' attention and stimulate for student learning. In addition, Civics lessons are also less desirable by the students because learning Civic education in schools so far in general many done with conventional learning models or lectures.

There are two things that tend to be the cause: (1) the existing Civic learning facilities in the school are very limited, (2) the teacher's understanding of the science of civic education and learning is still not optimal. Education also has a purpose, while the purpose of the Civic Education course is that students have the following skills: Think critically, rationally, and creatively in responding to citizenship issues, Participate actively and responsibly, and act intelligently in the activities of society, nation, and state, and anti-corruption, Developing positively and democratically to establish themselves based on the characters of Indonesian society to be able to live together with other nations.

Based on the background above, the author try to improve student learning outcomes by using cooperative learning model with STAD type (student team achivement divisions). Cooperative learning refers to a variety of teaching methods where students work in small groups to help each other in learning the subject matter. In the cooperative class, students are expected to help each other, discuss each other and argue, to hone their current skills and close the gaps in their respective understandings. In relation to

\footnotetext{
${ }^{1}$ Peraturan Menteri Pendidikan Nasional Nomor 41 tahun 2007 tentang Standar Proses dan Peraturan Menteri Pendidikan Nasional Nomor 16 tahun 2007 tentang Standar Kualifikasi Guru
} 


\section{The Influence of Student Team Achievement (STAD) to the Students' Learning \\ Outcomes in Civics Subject at State Senior High School 7 Binjai \\ DOI: 10.30575/2017/IJLRES-2018010410}

existing problems and based on the theory put forward, the author with this want to do research with the title Influence of cooperative learning model STAD (Student team achievement division) on student learning outcomes in the subjects of Civics.

\section{LITERATURE REVIEW}

\section{STAD Teaching Model}

According to Slavin STAD (Student team achievement divisions) is the most widely studied variation of cooperative learning. In the STAD students are divided into groups of four people varying ability, gender and tribe. Salvin explained further that STAD is the main idea that encourages students to encourage each other and help one another master the skills that teachers teach. According to Slavin STAD is a common method of organizing a class rather than a comprehensive teaching method in teaching in a particular subject ${ }^{2}$.

The cooperative learning steps STAD model are as follows:

a. Submission of learning materials to students according to basic competencies to be achieved.

b. Teachers give tests or quizzes to students individually so that will get the initial value of student ability.

c. Teachers form groups, with each group consisting of 4 to 5 members, where each group member has different academic abilities.

d. The teacher assigns the task to the group in relation to the material given.

e. Teachers provide tests or quizzes to each student individually.

f. Teachers facilitate students in making summaries, directing and affirming learning materials that have been learned.

g. Teachers reward groups based on the value of improving individual learning outcomes from the initial score to the next quiz nialai.

${ }^{2}$ Robert E Slavin (1995). Cooperative Learning: Theory, Research and Practice, 2nd Edition. New York. Pearson. 


\section{The Advantages of STAD Learning Model}

Students work together in achieving their goals by upholding group norms, actively helping students and motivating the spirit to succeed together, actively acting as peer tutors to further enhance group success, interaction among students as they improve their ability to argue, improve individual skills, improve group skills, not competitive, have no sense of resentment.

\section{The Weakness of STAD Learning Model}

The contribution of low-achieving students becomes less, high achieving students will lead to disappointment because the role of clever members is more dominant, requires a longer time so in general the teacher does not want to use cooperative learning, requires special skills so that not all teachers can do cooperative learning, according to the particular nature of the student, such as the nature of the likes of working together.

\section{Civics Education}

Citizenship education is expected that Indonesian intellectuals have a basic personality as citizens who are democratic, religious, humanitarian, and civilized. According to Kaelan Citizens also have an obligation to the state and vice versa citizens also have rights that must be given and protected by the state. Subject Civic education is a vehicle for developing and preserving noble and moral values rooted in Indonesian culture. Implementation embodied in the form of daily life behavior, as contained in Law No. 20 of 2003 namely: "behavior in everyday life must be imbued Pancasila values". The education of Pancasila and Citizenship is intended to provide students with noble character, basic knowledge and ability with regard to the relations between citizens and countries, and basic education to defend the state to become citizens who can be relied upon by the nation and state.

\section{METHODOLOGY}

Implementation of the research conducted in SMA N 7 Binjai, while the reason factors so that researchers choose this place as the location of research is for more accurate source of information, and also because the location to be studied can be 
reached and get direct information from teachers of Civics study area in the place of teaching research carried out the method used koerelasi and descriptive method.

Table 1 Research Action Plan

\begin{tabular}{|l|l|l|l|l|l|l|l|l|l|l|}
\hline \multirow{2}{*}{ No } & \multirow{2}{*}{ Activities } & \multicolumn{9}{|c|}{ Month } \\
\hline & & Mar & Apr & May & Jun & Jul & Aug & Sep & Okt & Nov \\
\hline 1 & Pre- Observation & $\sqrt{ }$ & & & & & & & & \\
\hline 2 & Proposal Framing & & $\sqrt{ }$ & & & & & & & \\
\hline 3 & $\begin{array}{l}\text { Proposal } \\
\text { Supervisory }\end{array}$ & & & $\sqrt{ }$ & $\sqrt{ }$ & $\sqrt{ }$ & & & & \\
\hline 4 & Seminar of Proposal & & & & & & & $\sqrt{ }$ & & \\
\hline 5 & Data Collection & & & & & & & & $\sqrt{ }$ & \\
\hline 6 & Presentation & & & & & & & & & $\sqrt{ }$ \\
\hline
\end{tabular}

Table 2 Total of Students of Class X

\begin{tabular}{|c|r|r|}
\hline Number & Grade & Student Amount \\
\hline 1. & X-IPS 1 & 36 \\
\hline 2. & X- IPS 2 & 36 \\
\hline 3. & X- IPS 3 & 36 \\
\hline \multicolumn{2}{|c|}{ Total of Students of Class X IPS } & $\mathbf{1 0 8}$ \\
\hline
\end{tabular}

According to Sugiono Sample is part of the number and characteristics possessed by that population. So the Sample is a trying person who becomes the data source representing the whole of the population. The sampling technique used by researchers is simple random sampling technique. Simple random sampling technique is taking the sample members of the population done randomly. Type of research used in this study is experimental research. And the method used is quantitative method. According Sugiyono The variable research Hatch and Farhady reveals that, the variable is defined as an attribute of a person or object that has variations between one person to another or one object with another object. Variables can be attributes of a particular field of science or activity. The variable in this study is STAD cooperative learning model as free variable (x) and learning outcomes on the subject of Civics is the dependent variable (y). The variables of this study when translated are: free variable is the variable that affects or which causes the change or the emergence of the dependent variable. In this study the free variable $(x)$ is the cooperative method STAD. Variable which influenced or which become due to the existence of free variable. The dependent variable (y) is the result of learning on the ppkn subject. 
Normality testing is done to determine whether or not a normal distribution of data. It is important to know in relation to the determination of the selection of statistical tests to be used. Normal testing here should be done if there is no theory that states that the variables studied are normal. In other words, if there is a theory that states that a variable being studied is normal, then no longer required testing of data normality.After this research data collected ie test results given then the data will be analyzed by the steps as follows:

1. Determining Mean

By using the formula :

$\bar{x}=\frac{\Sigma x_{i}}{n}$

$\bar{Y}=\frac{\Sigma Y_{i}}{n}$

2. Standard of Deviation

$S_{x}=\sqrt{\frac{n \Sigma x^{2}-(\Sigma x)^{2}}{n(n-1)}}$

$\mathrm{S}_{\mathrm{y}}=\sqrt{\frac{n \Sigma Y^{2}-(\Sigma Y)^{2}}{n(n-1)}}$

\section{Homogenity Test of data}

Homogeneity testing is about the variance of two or more distributions. Homogeneity test is done to find out whether the data in variables $X$ and $Y$ are homogeny or not. To test whether the homogeneous data will be tested the following hypothesis:

$\mathrm{H}_{\mathrm{O}: \rho=0}$

Ha : $\rho \neq 0$

\section{Hypothesis Test}

1. Correlation Test

The formula used to analyze the relationship between independent variables and dependent variable authors use the formula of product moment correlation.

$$
\begin{aligned}
& \mathrm{r}_{\mathrm{xy}}=\frac{\Sigma x y}{\sqrt{\left(\Sigma x^{2}\right)\left(\Sigma y^{2}\right)}}
\end{aligned}
$$

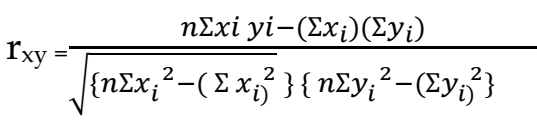


The Influence of Student Team Achievement (STAD) to the Students' Learning Outcomes in Civics Subject at State Senior High School 7 Binjai DOI: 10.30575/2017/IJLRES-2018010410

Table 3 Guidelines for Giving Interpretation of Correlation Coefficients

\begin{tabular}{|l|l|}
\hline \multicolumn{1}{|c|}{ Interval Co Efficient } & \multicolumn{1}{|c|}{ Relationship Level } \\
\hline $0,00-0,199$ & Very Low \\
$0,20-0,399$ & Low \\
$0,40-0,599$ & Middle \\
$0,60-0,799$ & Strong \\
$0,80-0,100$ & Very Stromg \\
\hline
\end{tabular}

After that, then tested significantly with product moment correlation with the formula, $\mathrm{t}=\frac{r \sqrt{n-2}}{\sqrt{1-r^{2}}}$

2. Make a conclusion in terms of acceptance and rejection $\mathrm{H}_{0}$, Accepted test criteria if $t>t(1-a)$, to a real level $\alpha=0,05$ and $d k=(n-2)$ in other case Ho is rejected.

\section{FINDINGS AND DISCUSSION}

In this study the researchers used one pretest and one postest which aims to obtain learning outcomes before and after using cooperative STAD learning model. This research was conducted to 20 students as respondents who were taken by using simple random sampling technique or taking sample members from random population.

\section{Diagram "Batang pretest"}

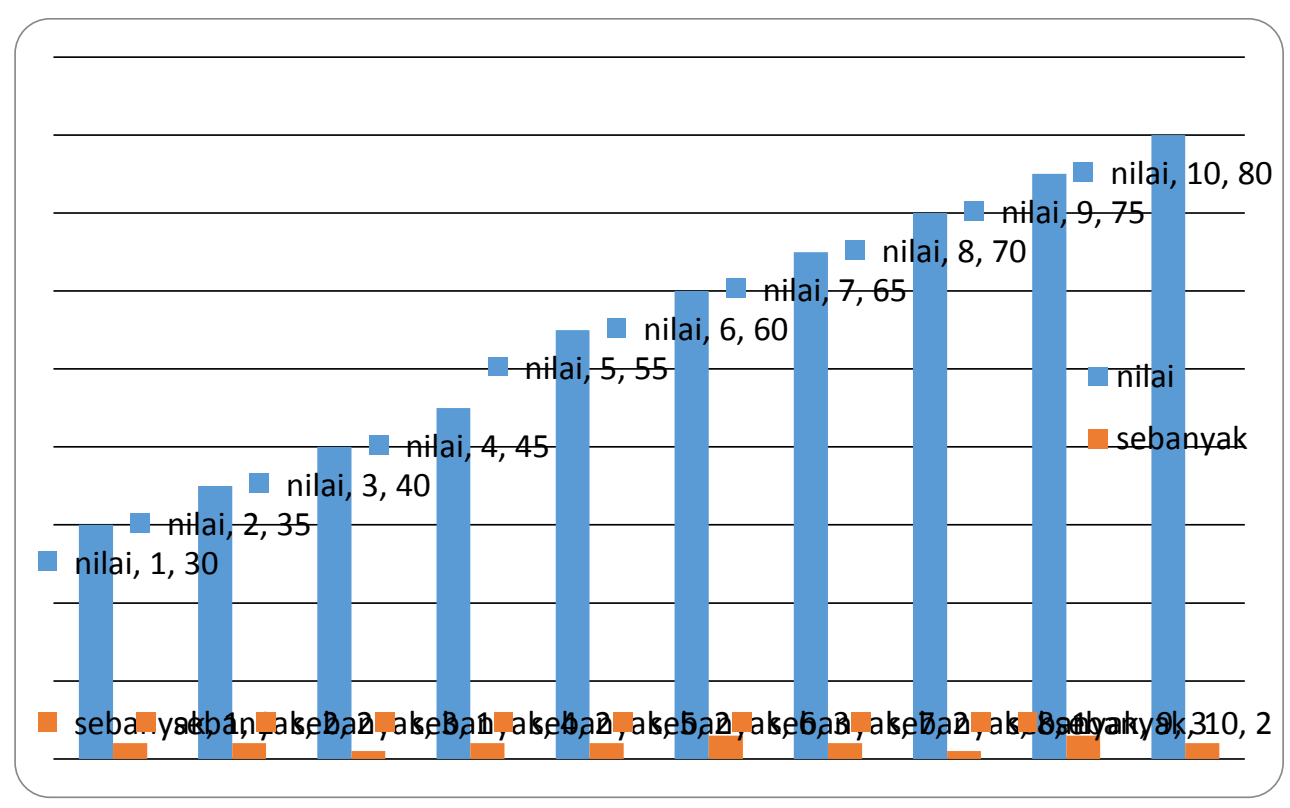




\section{Diagram "Batang post test"}

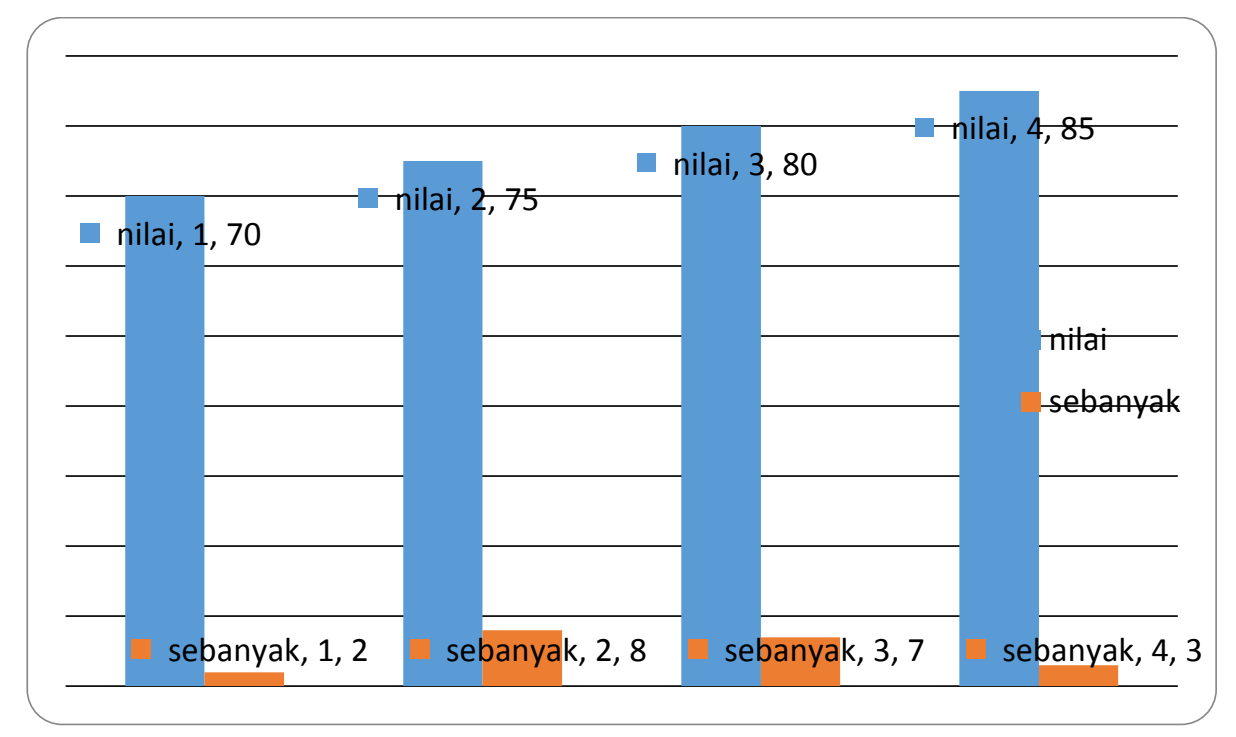

\section{Test of Normality}

\section{Students Pretest Results (X)}

The following is the conclusion of the pretest data of the students that have been collected by the researcher.

From the results of data collection, sought the average student score and standard deviation follows:

$$
\begin{aligned}
\bar{x} & =\frac{\sum x_{i}}{n} \\
\bar{x} & =\frac{1135}{20} \\
& =56,75
\end{aligned}
$$

And the standard deviation is

$$
\begin{aligned}
& S_{x}=\sqrt{\frac{n \sum x^{2}-\left(\sum x\right)^{2}}{n(n-1)}} \\
& S x=\sqrt{\frac{20(69775)-1288225}{20.19}}
\end{aligned}
$$

$$
=282.30
$$


The Influence of Student Team Achievement (STAD) to the Students' Learning

Outcomes in Civics Subject at State Senior High School 7 Binjai

DOI: 10.30575/2017/IJLRES-2018010410

In the pretest result the students obtained the average score of 56.75 students and the standard deviation of 282.30 .

\section{Postest result of student $(\mathrm{Y})$}

From the results of data collection, look for the average student score and standard deviation follows:

$\bar{Y}=\frac{\Sigma Y_{i}}{n}$

$\bar{Y}=\frac{1555}{20}=77,75$

Dan standart deviasinya ialah

$\mathrm{S}_{\mathrm{y}}=\sqrt{\frac{n \Sigma Y^{2}-(\Sigma Y)^{2}}{n(n-1)}}$

$S_{y}=\sqrt{\frac{24(121275)-2418025}{20.19}}=1296.1184$

In the student's post test results obtained the average student score of 77.75 and the standard deviation is 1296.11 .

\section{Normality Test of Pre-test}

From the above data it can be seen that $1_{-}(\mathrm{o}=1.28)$ and for $1_{-}($table $=0,190)$. Thus $1 \_o\left(1.28<1 \_t a b l e(0.190)\right.$, so the data obtained is Normal.

$X=77,75$

$S=\sqrt{54990,6}=234,50$

\section{Normality Test of Post test}

The data can be viewed in Appendix 10, in Table 4.4, and on page 64. From the table above it is known that $1 \_\mathrm{o}=0.0575$ with $\mathrm{n}-20$ and the level of $a=0.05$ is 0.190 thus $1 \_\mathrm{o}=$ $0.0575<0.190$. Conclusion that the data is normally distributed.

$X=77,75$

$S=\sqrt{54990,6}=234,50$ 


\section{Homoginity Test of Data}

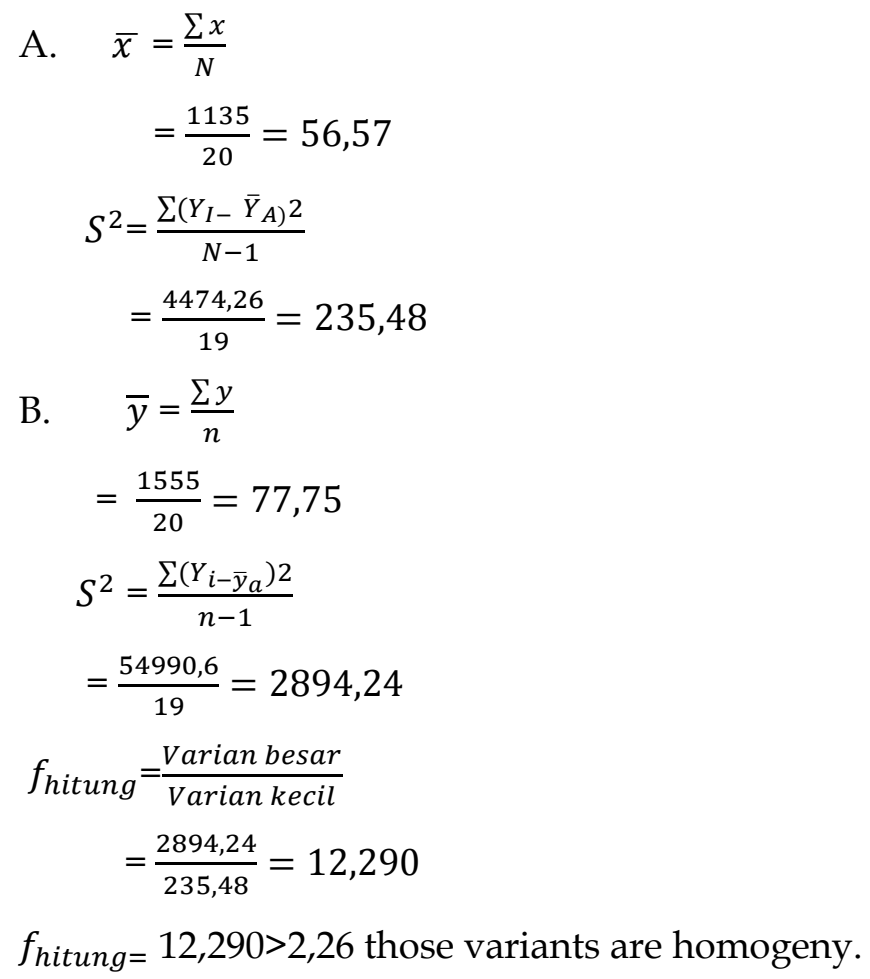

\section{The Test of Homoginity}

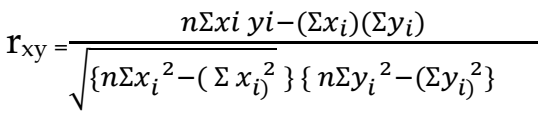

$$
\begin{aligned}
& =\frac{20(84725-(1135)(1555)}{\sqrt{\left(20(69775)-(1135)^{2}\left(20(121275)-(1555)^{2}\right)\right.}} \\
& =\frac{1694500-1764925}{\sqrt{(1395500-1288225)(2425500-2418025)}} \\
& =\frac{-70425}{\sqrt{(107275)(7475)}}=\frac{-70425}{\sqrt{801880625}} \\
& =\frac{-70425}{28317,49}=2,48
\end{aligned}
$$

Conclusion:

$r_{h}=2,48$ and $r_{t}$ placed 0,444 . So there is influence of Cooperative STAD learning model on student learning outcomes in the eyes of Civics class X SMA 7 Binjai. With $r_{\text {hitung }}(2,48)$ and $r_{\text {tabel }}(0,444)$. 
The Influence of Student Team Achievement (STAD) to the Students' Learning

Outcomes in Civics Subject at State Senior High School 7 Binjai

DOI: 10.30575/2017/IJLRES-2018010410

After that a significant test of product moment correlation with the formula

$$
\begin{aligned}
t & =\frac{r \sqrt{n-2}}{\sqrt{1-r^{2}}} \\
& =\frac{2,48 \sqrt{20-2}}{\sqrt{1-2,48^{2}}} \\
& =\frac{2,48(4,24)}{\sqrt{1-6,1504}}=\frac{10,5152}{\sqrt{5,1504}} \\
& =\frac{10,5152}{2,26}=4,65
\end{aligned}
$$

Therefore, $t_{\text {hitung }} 4,65>1,73$.

From those $r_{\text {tabel }}$ shows that there is an influence between the two variables.

\section{CONCLUSSION}

From the results of the research, it can be concluded that:

1. The average score of the pretest of students is 56.75 with the standard deviation of 282.30. And for the average value of the student postest of 77.75 with the standard deviation of 1296.1184

2. The homogeneity test value of pretest data is 235.48. And the test value of homogeneity of postest is 2894,24

3. From result of calculation of hypothesis test got $r_{-} h=2,48$ and $r \_t$ lies 0,444 . So there is influence of Cooperative STAD learning model on student learning outcomes in the eyes of Civics class X SMA 7 Binjai. With $r_{-}$(count) (2.48) and r_tabel (0.444). With $t_{-}$(count) $4.65>1.73$. From $r_{-}$(table) it shows that there is influence between two variables.

\section{BIBILIOGRAPHY}

Djamarah, S. B (2013). Strategi Belajar Mengajar, Jakarta, Rineka Cipta.

Huda, M. (2014). Model-Model Pengajaran Dan Pembelajaran,Yogyakarta:Pustaka Pelajar.

Kaelan, M.S. (2010). Pendidikan Kewarganegaraan.Yogyakarta: Paradigma.

Margono, S. (2013). Metodologi Penelitian Pendidikan, Jakarta, Asdi Mahasatya.

Purwanto, (2009). Evaluasi Hasil Belajar, Yogyakarta, Pustaka Pelajar.

Rusman, (2014). Model-Model Pembelajaran, Jakarta, Raja Grafindo Persada.

Shoimin, A, (2014). 68 Model Pembelajaran Inovatif Dalam Kurikulum 2013, Yogyakarta: ArRuzz. 


\section{Heryansyah Ginting}

Slavin, R. E. (1995). Cooperative Learning: Theory, Research And Practice, 2nd Edition. New York. Pearson.

Sugiyono, (2013). Metode Penelitian Pendidikan, Alfabeta, Bandung.

Trianto, (2009). Mendesain Model Pembelajaran Inovative-Progresif, Jakarta: Kencana Prenada Media Group. 